\title{
The impact of chronic pseudomonal infection on pulmonary function testing in individuals with cystic fibrosis in Pretoria, South Africa
}

\author{
A Pentz, FC Paed (SA), Dip Allergol (SA); P Becker, PhD; R Masekela, PhD; O Coetzee, N Dip Clin Tech; R J Green, PhD, DSc \\ Department of Paediatrics and Child Health, Faculty of Health Sciences, University of Pretoria, South Africa
}

Corresponding author: RJ Green (robin.green@up.ac.za)

Background. Colonisation of the airway by Pseudomonas spp. in cystic fibrosis has been reported to be an important determinant of decline in pulmonary function.

Objective. To assess pulmonary function decline and the presence of bacterial colonisation in patients with cystic fibrosis (CF) attending a CF clinic in a developing country.

Methods. A retrospective audit of patients attending the CF clinic at Steve Biko Academic Hospital, Pretoria, South Africa, was performed. The data included spirometric indices and organisms routinely cultured from airway secretions (Pseudomonas aeruginosa (PA) and Staphylococcus aureus (SA)).

Results. There were 29 study subjects. Analysis of variance for ranks (after determining that baseline pulmonary function, age, gender and period of follow-up were not contributing to pulmonary function decline) revealed a median decline in forced expiratory volume in 1 second, forced vital capacity and forced expiratory flow over 25 - 75\% expiration of $12 \%, 6 \%$ and $3 \%$, respectively, for individuals colonised by PA. There was no pulmonary function decline in individuals not colonised by PA, or in individuals colonised by SA.

Conclusion. Pulmonary function decline in this South African centre is significantly influenced by chronic pseudomonal infection. Other influences on this phenomenon should be explored.

S Afr Med J 2014;104(3):191-194. DOI:10.7196/SAMJ.7222

Cystic fibrosis (CF) is a genetic disease with an autosomal recessive inheritance pattern. The identified gene, the cystic fibrosis transmembrane conductance regulator (CFTR), is situated on the long arm of chromosome $7 \cdot{ }^{[1]}$ The pathological features in CF follow an abnormality or dysfunction in the CFTR gene leading to abnormal transport of chloride and sodium across epithelial membranes. This involves the pancreas, biliary tract, intestines, reproductive tract, airway and sweat glands, and in the airway leads to airway dehydration and disruption of mucociliary clearance. As a result of abnormal airway 
secretions, mucus becomes a nidus for regular infections by microorganisms. ${ }^{[2]}$ The predominant organisms are Staphylococcus aureus (SA) and Pseudomonas aeruginosa (PA). ${ }^{[3}$

Colonisation by PA has major consequences for individuals with CF, including more frequent respiratory infectious exacerbations, impaired quality of life, growth retardation and decline in pulmonary function. ${ }^{[4]}$ The concept of colonisation of the CF airway is the subject of significant debate. Some authors consider that recurrent culture of PA from airway secretions constitutes 'chronic infection' rather than colonisation, since the latter term implies benign presence of organisms. ${ }^{[5]}$ In the current study, colonisation was considered to occur when the same bacterium was isolated in at least three sputum specimens on three different occasions but not during an acute exacerbation.

Colonisation by PA has been reported to be the most important determinant of decline in lung function in subjects with $\mathrm{CF}^{[6]}$ Many CF centres around the world have employed measures to minimise the risk of, and from, PA. These measures include separation of chronically colonised patients from those without PA at clinics, aggressive eradication policies, and nebuliser and home hygiene.

Spirometric measurements of pulmonary function (particularly forced expiratory volume in 1 second $\left(\mathrm{FEV}_{1}\right)$ ) are important measures of disease progression and survival in $\mathrm{CF} .^{[7]}$

The rate of annual pulmonary function decline, as well as the associated or aetiological factors, have been explored in some population groups. ${ }^{[8,9]}$ In South Africa, only two studies of pulmonary function decline in CF have been published. ${ }^{[10,11]}$

The aim of the current study was to compare the association between pulmonary function measurements and the presence of bacterial colonisation by PA and SA in patients with CF attending the clinic at Steve Biko Academic Hospital (SBAH), Pretoria, South Africa.

\section{Methods}

A retrospective audit of the patient records of subjects followed up at the CF clinic at SBAH was performed. The data analysed included spirometry, organisms identified on regular sputum microbial culture, and other epidemiological variables (age at CF diagnosis, age at first recorded spirometry, first spirometric parameters, identification of PA or SA in sputum (if ever), last spirometry indices, and spirometry parameters performed in the middle of the period between the first and last spirometry). Subjects met the inclusion criteria if they had $\mathrm{CF}$, had records of at least three pulmonary function tests, and were able to contribute sputa for determination of microbial colonisation, not associated with an acute exacerbation. CF had been diagnosed on the basis of two unequivocal sweat tests and confirmed by genetic testing in all subjects.

Patients were enrolled if they were able to perform reliable spirometry. It was then determined whether or not each of these patients had current sputum growth of PA (December 2012). The individuals with PA in sputa were then enrolled as PA-positive if they had grown the organism on three or more occasions in the last year. At each of these time points the growth was associated with spirometry performed at that visit.

All patients had sputum collected by expectoration or induced with hypertonic saline by nebulisation under supervision of a physiotherapist. Sputa were routinely collected from every patient at every clinic visit. Sputum quality was ensured as representative of lower airway secretions by means of a Bartlett score.

The CF clinic at SBAH has 52 current patients, ranging in age from 8 months to 40 years. Most of the white patients are $\Delta$ F508 homozygous or heterozygous, but the clinic has four black African and mixed-race CF patients with other genetic aetiologies. Ninety per cent of the patients have pancreatic insufficiency. Clinic practice includes regular attempts to eradicate $\mathrm{PA}$ when it is identified for the first time, and patients with PA are treated in separate areas. The clinic manages all patients according to guidelines published by the Medical and Scientific Advisory Committee of the South African Cystic Fibrosis Association. Two clinic members are executive participants. ${ }^{[12]}$

Spirometry was performed using a Koko legend spirometer (manufactured by nSpire Health, Inc. and supplied by SSEM Mthembu). Normal values were interpreted against the European Respiratory Society (ERS)/Polgar predicted values ${ }^{[13]}$ and in accordance with the ERS criteria. ${ }^{[14]}$ The best pulmonary function test value (based on $\mathrm{FEV}_{1}$ ) of three reproducible efforts (without bronchodilator administration) was recorded. $\mathrm{FEV}_{1}$, forced vital capacity (FVC), and forced expiratory flow over 25 - 75\% expiration $\left(\mathrm{FEF}_{25-75}\right)$ were recorded. A new decontaminated re-usable bacterial filter (Vibac Pulmonary Function filter) was used for each patient to prevent infectious cross-contamination. Spirometry was performed by a trained technician and equipment was calibrated daily. All values were expressed as percentages of expected, for age and height.

The study was approved by the Human Ethics Committee of the University of Pretoria.

\section{Statistical analysis}

As the data were skewed, analysis of variance (ANOVA) for ranks was conducted. The important analysis in the study was PA and SA colonisation in relation to spirometric indices. Because baseline pulmonary function, age, gender and period of follow-up were not found to be significant co-variates, an ANOVA for ranks was employed to assess PA and SA respectively, not adjusting for the latter. For change in spirometry the median and interquartile range (IQR) were reported. Stata 12 was used for analyses and $p \leq 0.05$ was considered significant.

\section{Results}

There were 29 study subjects (median age 9.97 years, IQR 6.79 21.14) who met the criteria for inclusion in the study. CF genetic analysis revealed that 15 individuals were $\Delta \mathrm{F} 508$ homozygous and eight were $\Delta$ F508 heterozygous. The remaining six individuals had other less common mutations. Spirometry indices at baseline revealed a median (IQR) $\mathrm{FEV}_{1}, \mathrm{FVC}$ and $\mathrm{FEF}_{25-75}$ of $78 \%$ (61 - 101), $87 \%$ (73 - 95) and 70\% (38 - 106), respectively. At the end of the study, spirometry indices revealed a mean (IQR) $\mathrm{FEV}_{1}, \mathrm{FVC}$ and $\mathrm{FEF}_{25-75}$ of $61 \%(49-94), 77 \%(52-94)$ and $43 \%$ (22 - 107), respectively. These were not statistically different for the total group $(p>0.05)$. The median (IQR) of the spirometric variables for the patients colonised by PA, and those not colonised, for the study entry time point and study end time point are reflected in Table 1. As baseline pulmonary function, age, gender and period of follow-up were not found to be significant covariates, an ANOVA for ranks was employed to assess the impact of PA and SA, respectively, on change in spirometric indices without adjusting for the latter (Table 2).

With respect to colonisation of sputa by PA, 15 of the subjects attending the clinic (51.7\%) were found to be colonised at study entry. The median age of the patients with PA colonisation was 19.9 years (IQR 15.8 - 26.9).

The interaction of SA and PA in individuals colonised by both organisms revealed no statistical significance for any spirometric parameter. There were three patients colonised by both organisms.

There was no difference in the rate of decline of pulmonary function between individuals with the common genetic mutation ( $\Delta$ F508) homozygous status, those with heterozygous status, or when another mutation was present ( $p>0.05$ for all indices). 


\begin{tabular}{|c|c|c|}
\hline & $\begin{array}{l}\text { Study start } \\
\text { median (IQR) }\end{array}$ & $\begin{array}{l}\text { Study end } \\
\text { median (IQR) }\end{array}$ \\
\hline \multicolumn{3}{|l|}{$\mathrm{FEV}_{1}$} \\
\hline Total group & $78(61-101)$ & $61(49-94)$ \\
\hline PA-negative & $99.5(78-105)$ & $97(60-107)$ \\
\hline PA-colonised & $71(41-83)$ & $50(23-68)$ \\
\hline \multicolumn{3}{|l|}{ FVC } \\
\hline Total group & $87(73-95)$ & $77(52-94)$ \\
\hline PA-negative & $93(81-104)$ & $97(71-114)$ \\
\hline PA-colonised & $84(56-87)$ & $67(41-80)$ \\
\hline \multicolumn{3}{|l|}{$\mathrm{FEF}_{25-75}$} \\
\hline Total group & $70(38-106)$ & $43(22-107)$ \\
\hline PA-negative & $105(55-118)$ & $109(69-138)$ \\
\hline PA-colonised & $38(18-87)$ & $22(11-42)$ \\
\hline
\end{tabular}

Table 2. Change in pulmonary function variables over time in individuals with cystic fibrosis*

\begin{tabular}{|c|c|c|}
\hline $\begin{array}{l}\text { Outcome (change } \\
\text { from baseline) }\end{array}$ & $\begin{array}{l}\text { Median (change from } \\
\text { baseline) (IQR) }\end{array}$ & $p$-value \\
\hline \multicolumn{3}{|l|}{$\mathrm{PA}$} \\
\hline $\mathrm{FEV}_{1}$ & & 0.028 \\
\hline Negative & $-2(-10-10)$ & \\
\hline Positive & $12(2-22)$ & \\
\hline FVC & & 0.010 \\
\hline Negative & $-7(-12-4)$ & \\
\hline Positive & $6(4-18)$ & \\
\hline $\mathrm{FEF}_{25-75}$ & & 0.015 \\
\hline Negative & $-18.5(-28-14)$ & \\
\hline Positive & $3(-1-22)$ & \\
\hline \multicolumn{3}{|l|}{ SA } \\
\hline $\mathrm{FEV}_{1}$ & & 0.393 \\
\hline Negative & $6(1-19)$ & \\
\hline Positive & $1(-6-12)$ & \\
\hline FVC & & 0.730 \\
\hline Negative & $4(-6,5-17,5)$ & \\
\hline Positive & $0(-8-18)$ & \\
\hline $\mathrm{FEF}_{25-75}$ & & 0.679 \\
\hline Negative & $4(-22-15)$ & \\
\hline Positive & $-1(-23-25)$ & \\
\hline $\begin{array}{l}\text { ANOVA = analysis of vari } \\
\mathrm{FEV}_{1}=\text { forced expiratory } \mathrm{v} \\
\mathrm{FEF}_{2.575}=\text { forced expiratory } \\
{ }^{*} \mathrm{ANOVA} \text { for ranks contro }\end{array}$ & $\begin{array}{l}\mathrm{R}=\text { interquartile range; } \mathrm{PA}=P_{S} \\
\mathrm{n} 1 \mathrm{second;} \text { FVC }=\text { forced vital } \\
\text { er } 25-75 \% \text { expiration; } \mathrm{SA}=\mathrm{St} \\
\text { baseline spirometry. }\end{array}$ & $\begin{array}{l}\text { lonas aerugir } \\
\text { y; } \\
\text { ccus aureus. }\end{array}$ \\
\hline
\end{tabular}

\section{Discussion}

This study supports the hypothesis that that the pulmonary function of patients with positive Pseudomonas spp. cultures declines significantly over time, independent of starting pulmonary function, subject age or gender and period of follow-up. It is possible that the presence of $\mathrm{PA}$ is but a marker for another process that may or may not be related to the presence of PA. However, this seems unlikely in the light of what is known about PA. It is well known that CF leads to a decline in pulmonary function. However, this decline is different in different population groups. ${ }^{[10,15,16]}$

The median age of the patients colonised by PA (19.9 years) in this study is significantly older than in many European centres, but this age is not the age of first colonisation. ${ }^{[17,18]}$ The high rate of PA colonisation in the study subjects $(51.7 \%)$ is greater than in some international studies, ${ }^{[9]}$ but is comparable to local SA studies. ${ }^{[10,11]}$

Even at study entry, patients who were colonised by PA had lower spirometric indices compared with patients who were not colonised at that stage $\left(p=0.014,0.0014\right.$ and 0.0061 for $\mathrm{FEV}_{1}$, FVC and $\mathrm{FEF}_{25-75}$, respectively). These findings mirror those of many, but not all, local and international studies and suggest that even in the developing world, where CF services may not be as robust as in the developed world, pulmonary function decline can be prevented if PA prevention and/or eradication is aggressively pursued. PA prevention and/or eradication may turn out to be the most costeffective intervention for $\mathrm{CF}$ individuals in developing countries. The current study revealed that a decline in pulmonary function was seen only in patients colonised with PA, and not in the group without colonisation, and that this was true for all spirometric indices ( $p<0.05$ for all parameters). However, this has not been a consistent finding in all studies, Amin et al ${ }^{[19]}$ in Canada having found that PA was not responsible for a decline in lung function. In contrast, in a UK study by Taylor-Robinson et al., ${ }^{[1]]} \mathrm{PA}$ infection was associated with a more rapid rate of lung function decline. Similar results, with pulmonary decline, were reported in the USA and the UK. ${ }^{[4,2022]}$

In a study conducted among Swedish CF patients, overall lung function was well preserved with a low rate of annual decline. However, a more rapid lung function decline was evident in the group colonised by PA. ${ }^{[9]}$ Similar results were obtained in the two studies performed in the Western Cape, South Africa ${ }^{[10,11]}$ in which the study populations with CF more closely resembled the current SBAH study. Pulmonary function decline may be expected to be more significant in CF subjects living in a developing country, where healthcare resources may not be as available as in the developed world. However, the current study reflects local and international data revealing that lung function decline is minimal in patients not colonised by PA.

Certain strains of PA, not determined in the current study, have been found to be more significantly associated with pulmonary function decline, as revealed in a Canadian study conducted by Aaron et al ${ }^{[8]}$ and in contrast to studies in Australia and the UK.

In a study by Davies et al. ${ }^{[23]} \mathrm{PA}$ infection in patients with non-CF bronchiectasis was shown to be a marker of disease severity, but was not linked to an accelerated decline in pulmonary function.

Other micro-organisms may be important in contributing to a decline in pulmonary function. The effect of multiple antibioticresistant PA infection on the decline of pulmonary function was found not to be significant in a study by Ren et al. ${ }^{[24]}$ Furthermore, compared with SA alone, SA in combination with PA has been found to be more deleterious. ${ }^{[3]}$ This was not found in the current study, but the number of individuals with both SA and PA was small. Aspergillus spp. sensitisation and persistent carriage lead to a more rapid decline in lung function. ${ }^{[25]}$ Similarly, airway colonisation with Candida albicans predicts a greater rate of $\mathrm{FEV}_{1}$ decline and hospital-treated exacerbations in $\mathrm{CF}^{[26]}$ These are factors that could have contributed to the lung function decline in the current study, but analysis of these organisms was not included. 
Another finding in the SBAH study was that there was no significant difference in the spirometric indices for males and females. This may reflect the small sample size, but was interesting as two studies have documented a difference in lung function decline between males and females. ${ }^{[27,28]}$ However, this finding is not consistent. In studies by Que et al. ${ }^{[22]}$ in London and Arrington-Sanders et al. ${ }^{[30]}$ in the USA, no significant differences in $\mathrm{FEV}_{1}$ between male and female patients was observed. Different populations behave differently, and there is therefore a real need to study this aspect in all regions of the world. Additionally, studies have found that female patients are at greater risk of being colonised by PA and have a poorer prognosis and decreased survival compared with male patients. ${ }^{[31,32]}$

With regard to the spirometric index $\mathrm{FEF}_{25-75}$, this study revealed a marked difference between patients colonised by PA and those who were not colonised, with a significantly greater rate of change in the former group. Although this is debated, the obstruction to small airways is best described as $\mathrm{FEF}_{25-75}$ measurements, and these measurements are considered to be more sensitive than $\mathrm{FEV}_{1}{ }_{1}{ }^{[33]}$ Numerous previous studies have revealed a decline in $\mathrm{FEF}_{25-75}$ over time in patients with $\mathrm{CF}^{\left[{ }^{[3-36]}\right.}$ It appears that PA has a very profound effect on this measure of airway function, and the current study reveals that it should be routinely performed in CF subjects, especially those colonised by PA.

\section{Study limitations}

This study was limited by the small sample size. Other limiting factors include lack of analyis of the multiple confounding factors that may be operational, including home environment, exposure to cigarette smoke, specific treatment modalities, differences between PA colonisation in males and females, and colonisation by different organisms. The fact that only three time points were analysed in the study may mask differences within these time points.

\section{Conclusion}

In this cohort of patients, carriage of PA was associated with worse pulmonary function measurements than in patients without PA when the first lung function tests were conducted, and with significant decline over time. Since this is not a universal finding, our study contributes meaningfully to the international database. Our findings also suggest that there are local variations in $\mathrm{CF}$ subjects and highlight the need to analyse data collected in every centre treating CF patients to uncover regional findings that may be important in guiding local health policy. Furthermore, the study highlights the discrepancies between spirometric indices in individuals with CF. More studies are required to investigate possible factors underlying these differences.

Presented at the Combined Congress of the South African Thoracic Society and the Allergy Society of South Africa, Sun City, South Africa, 5 - 9 June 2013.

Acknowledgement. The research was made possible by Department of Paediatrics research funds generated by publication outputs to the university by the Department of Higher Education, South Africa.

\footnotetext{
References

1. Derichs N. Targeting a genetic defect: Cystic fibrosis transmembrane conductance regulator modulators in cystic fibrosis. Eur Respir Rev 2013;22(127):58-65. [http://dx.doi.org/10.1183/09059180.00008412]
ing 2. Kunzelmann K, Schreiber R. Airway epithelial cells - hyperabsorption in CF? Int J Biochem Cell Biol 2012;44(8):1232-1235. [http://dx.doi.org/10.1016/j.biocel.2012.04.012]
}

3. Hubert D, Réglier-Poupet H, Sermet-Gaudelus I, et al. Association between Staphylococcus aureus alone or combined with Pseudomonas aeruginosa and the clinical condition of patients with cystic fibrosis. J Cyst Fibros 2013;12(5):S1569-S1993. [http://dx.doi.org/10.1016/j.jcf.2012.12.003]

4. Jarad NA, Higgs S. Factors associated with reduced $\mathrm{FEV}_{1}$ in adult patients with cystic fibrosis in a Jarad NA, Higgs S. Factors associated with reduced $\mathrm{FEV}_{1}$ in
relatively affluent area. Chron Respir Dis 2005;2(3):133-137.

relatively affluent area. Chron Respir Dis 2005;2(3):133-137.
5. Granström M, Ericsson A, Strandvik B, et al. Relation between antibody response to Pseudomonas 5. Granström M, Ericsson A, Strandvik B, et al. Relation between antibody response to Pseudomonas
aeruginosa exoproteins and colonization/infection in patients with cystic fibrosis. Acta Paediatr Scand 1984;73(6):772-777. [http://dx.doi.org/10.1111/j.1651-2227.1984.tb17774.x]

6. Lillquist YP, Cho E, Davidson AG. Economic effects of an eradication protocol for first appearance of Pseudomonas aeruginosa in cystic fibrosis patients: 1995 vs. 2009. J Cyst Fibros 2011;10(3):175-180. [http://dx.doi.org/10.1016/j.jcf.2011.01.002]

7. Konstan MW, Wagener JS, van Devanter DR. Characterizing aggressiveness and predicting future progression of CF lung disease. J Cyst Fibros 2009;8(Suppl 1):S15-S19. [http://dx.doi.org/10.1016/ S1569-1993(09)60006-0]

8. Aaron SD, Vandemheen KL, Ramotar K, et al. Infection with transmissible strains of Pseudomonas aeruginosa and clinical outcomes in adults with cystic fibrosis. JAMA 2010;304(19):2145-2153. [http:// dx.doi.org/10.1001/jama.2010.1665]

9. Dennersten U, Lannefors L, Höglund P, et al. Lung function decline in the aging Swedish cystic fibrosis . Dennersten L, Lannefors L, Hoglund P, et al. Lung function decline in the aging Swedish cystic fib
population. Respir Med 2009;103(7):1076-1082. [http://dx.doi.org/10.1016/.rmed.2009.01.020]

10. Morrow BM, Argent AC, Distiller GB, Zar HJ, Westwood ATR. Rate of pulmonary function decline
10 Morrow BM, Argent AC, Distiller GB, Zar HJ, Westwood ATR. Rate of pulmonary function decline
in South African children with cystic fibrosis. South African Journal of Child Health 2009;3(3):73-77.

1. Zar HJ, Moore B, Argent A, Ireland J, Westwood AT. Lung function in South African children with
1. Zar HJ, Moore B, Argent A, Ireland J, Westwood
cystic fibrosis. S Afr Med J 1998;88(8):994-997.

12. Medical and Scientific Committee of the South African Cystic Fibrosis Association. The South African Cystic Fibrosis Consensus Document 2012. 4th ed. Johannesburg: South African Cystic Fibrosis Association, 2012.

13. Quanjer PH, Borsboom GJ, Brunekreef B, et al. Spirometric reference values for white European children and adolescents: Polgar revisited. Pediatr Pulmonol 1995;19(2):135-142. [http://dx.doi. org/10.1002/ppul.1950190209]

14. Standardized lung function testing. Official statement of the European Respiratory Society. Eur Respir I Suppl 1993;16(Mar):S1-S100.

15. Schluchter MD, Konstan MW, Davis PB. Jointly modeling the relationship between survival and pulmonary function in cystic fibrosis patients. Stat Med 2002;21(9):1271-1287. [http://dx.doi. org/10.1002/sim.1104]

16. Taylor-Robinson D, Whitehead M, Dederichsen F, et al. Understanding the natural progression in Taylor-Robinson D, Whitehead $\mathrm{M}$, Dederichsen $\mathrm{F}$, et al. Understanding the natural progression in
$\% \mathrm{FEV}_{1}$ decline in patients with cystic fibrosis: A longitudinal study. Thorax 2012;67(10):860-866. [http://dx.doi.org/10.1136/thoraxjnl-2011-200953]

17. van Mansfeld R, Willems R, Brimicombe R, et al. Predictors of mucoid Pseudomonas colonization in cystic fibrosis patients. Pediatr Pulmonol 2008;43(5):463-471. [http://dx.doi.org/10.1002/ppul.20794] 18. Laurans M, Arion A, Fines-Guyon M, et al. Pseudomonas aeruginosa and cystic fibrosis: First colonization to chronic infection. Arch Pediatr 2006;13(Suppl 1):S22-S29.

19. Amin R, Lam M, Dupuis A, Ratjen F. The effect of early Pseudomonas aeruginosa treatment on lung function in pediatric cystic fibrosis. Pediatr Pulmonol 2011;46(6):554-558. [http://dx.doi.org/10.1002/ ppul.21417]

20. Hoffman LR, Kulasekara HD, Emerson J, Houston LS, Burns JL, Ramsey BVV. Pseudomonas aeruginosa lasR mutants are associated with cystic fibrosis lung disease progression. J Cyst Fibros 2009;8(1):66-70. [http://dx.doi.org/10.1016/j.jcf.2008.09.006]

21. Hunter RC, Klepac-Ceraj V, Lorenzi MM, Grotzinger H, Martin TR, Newman DK. Phenazine content in the cystic fibrosis respiratory tract negatively correlates with lung function and microbial complexity. Am J Respir Cell Mol Biol 2012;47(6):738-745. [http://dx.doi.org/10.1165/rcmb.20120088OC]

22. McPhail GL, Acton JD, Fenchel MC, Amin RS, Seid M. Improvements in lung function outcomes in children with cystic fibrosis are associated with better nutrition, fewer chronic Pseudomonas aeruginosa infections, and dornasealfa use. J Pediatr 2008;153(6):752-757. [http://dx.doi.org/10.1016/j. jpeds.2008.07.011]

23. Davies G, Wells AU, Doffman S, Watanabe S, Wilson R. The effect of Pseudomonas aeruginosa on pulmonary function in patients with bronchiectasis. Eur Respir J 2006;28(5):974-979. [http://dx.doi. org/10.1183/09031936.06.00074605

24. Ren CL, Konstan MW, Yegin A, et al. Multiple antibiotic-resistant Pseudomonas aeruginosa and lung function decline in patients with cystic fibrosis. J Cyst Fibros 2012;11(4):293-299. [http://dx.doi. org/10.1016/j.jcf.2012.02.005]

25. Fillaux J, Brémont F, Murris M, et al. Assessment of Aspergillus sensitization or persistent carriage as a factor in lung function impairment in cystic fibrosis patients. Scand J Infect Dis 2012;44(11):842-847. [http://dx.doi.org/10.3109/00365548.2012.695454]

26. Chotirmall SH, O’Donoghue E, Bennett K, Gunaratnam C, O’Neil SJ, McElvaney NG. Sputum Candida albicans presages $\mathrm{FEV}_{1}$ decline and hospital-treated exacerbations in cystic fibrosis. Chest 2010;138(5):1186-1195. [http://dx.doi.org/10.1378/chest.09-2996]

27. Corey M, Edwards L, Levison H, Knowles M. Longitudinal analysis of pulmonary function decline in patients with cystic fibrosis. J Pediatr 1997;131(6):809-814. [http://dx.doi.org/10.1016/S0022-
ing 3476(97)70025-8]

28. Konstan MW, Morgan WJ, Butler SM, et al. Risk factors for rate of decline in forced expiratory volume in one second in children and adolescents with cystic fibrosis. J Pediatr 2007;151(2):134-139. [http:// dx.doi.org/10.1016/j.jpeds.2007.03.006]

29. Que C, Cullinan P, Geddes D. Improving rate of decline of $\mathrm{FEV}_{1}$ in young adults with cystic fibrosis. Thorax 2006;61(2):155-157. [http://dx.doi.org/10.1136/thx.2005.043372]

30. Arrington-Sanders R, Yi MS, Tsevat J, Wilmott RW, Mrus JM. Gender differences in health-related quality of life of adolescents with cystic fibrosis. Health Qual Life Outcomes 2006;Jan 24;4:5.

1. Demko CA, Byard PJ, Davis PB. Gender difference in cystic fibrosis: Pseudomonas aeruginosa. J Clin Epidemiol 1995;48(8):1041-1049. [http://dx.doi.org/10.1016/0895-4356(94)00230-N]

32. Chotirmall SH, Smith SG, Gunaratnam C, et al. Effect of estrogen on Pseudomonas mucoidy and exacerbations in cystic fibrosis. N Engl J Med 2012;366(21):1978-1986. [http://dx.doi.org/10.1056/ NEJMoal106126]

33. Tiddens HAWM, Donaldson SHD, Rosenfeld M, Paré PD. Cystic fibrosis lung disease starts in the small airways: Can we treat it more effectively? Pediatr Pulmonol 2010;45(2):107-117. [http://dx.doi. org/10.1002/ppul.21154]

34. Cox DW, Kelly C, Rush R, O'Sullivan N, Canny G, Linnane B. The impact of MRSA infection in the airways of children with cystic fibrosis: A case-control study. Ir Med J 2011;104(10):305-308.

35. Lopes AJ, Mafort TT, de Sá Ferreira A, Santos de Castro MC, Cássia de Firmida M, de Andrade Marques $\mathrm{E}$. Is the type of chronic pulmonary infection a determinant of lung function outcomes in adult patients with cystic fibrosis? Monaldi Arch Chest Dis 2012;77(3-4):122-128.

36. Vilozni D, Lavie M, Sarouk I, Efrati O. Progressive flow-to-volume dysanapsis in cystic fibrosis: A predictor for lung transplantation? Am J Respir Crit Care Med 2012;186(1):82-87. [http://dx.doi. org/10.1164/rccm.201202-0272OC]

Accepted 7 November 2013. 